JURNAL SPORTA SAINTIKA

P-ISSN 2502-5651

E-ISSN 2579-5910

\title{
PENGARUH MINUMAN ISOTONIK TERHADAP DAYA TAHAN AEROBIK
}

\author{
Rika Sepriani ${ }^{1}$, Sepriadi $^{2}$ \\ ${ }^{1}$ Universitas Negeri Padang, Pendidikan Jasmani Kesehatan dan \\ Rekreasi, Padang, Indonesia \\ 2Universitas Negeri Padang, Pendidikan Jasmani Kesehatan dan \\ Rekreasi, Padang, Indonesia \\ rikasepriani@fik.unp.ac.id,sepriadi@fik.unp.ac.id
}

\begin{abstract}
The purpose of this research is to prove the benefits of isotonic drinks promised by the manufacturers. This is a quasi-experimental research design involving 20 non-athlete male students. The data were analyzed using t-test.From the data analysis, it was found that there was a significant difference between aerobic endurance before and after drinking isotonic drinks, $t_{\text {observe }}(5.398604)>t_{\text {table }}$ (1.729) at level significant $\alpha=0.05$. Based on the result of the research, it can be concluded that isotonic drinks has a significant effect towards students' aerobic endurance.
\end{abstract}

Keywords: Isotonic Drinks, Aerobic Endurance

\begin{abstract}
ABSTRAK
Penelitian ini bertujuan untuk melihat pengaruh minuman isotonik sesuai dengan yang dijanjikan oleh produsennya. Penelitian ini bersifat eksperimental semu dengan memberikan perlakuan kepada 20 orang mahasiswa laki-laki yang bukan atlet. Data yang diperoleh dianalisis dengan menggunakan statistik uji t. Dari analisis data didapatkan terdapat perbedaan yang signifikan daya tahan aerobik sebelum dan sesudah pemberian minuman isotonik dengan nilai thitung $(5,398604)>t_{\text {tabel }}(1,729)$ pada taraf signifikansi $\alpha=0,05$.
\end{abstract}

\section{Kata Kunci: Minuman isotonik, daya tahan aerobik}

\section{PENDAHULUAN}

Daya tahan merupakan salah satu komponen biomotorik yang sangatdibutuhkan dalam aktifitas fisik, dan salah satu komponen terpenting dari kesegaran jasmani. Daya tahan diartikan sebagai waktu bertahan yaitu lamanya seseorang dapat melakukan suatu intensitas kerja atau jauh dari keletihan. (Bafirman, 2008). Daya tahan (endurance) diartikan sebagai 
JURNAL SPORTA SAINTIKA

P-ISSN 2502-5651

E-ISSN 2579-5910

kesanggupan bekerja dengan intensitas tertentu dalam rentangan waktu yang cukup lama, tanpa kelelahan yang berlebihan. Kelelahan yang berlebihan akan menyebabkan seseorang tidak sanggup melakukan pekerjaannya. Namun secara umum dapatdikatakan bahwa, orang dianggap memiliki daya tahan, kalau masih sanggup bekerja terus menerus dalam periode waktu yang relatif lama (Sepriani \& Asnaldi, 2016). Keletihan yang berlebihan akan menyebabkan seseorang tidaksanggup melakukan pekerjaannya. Namun secara umum dapat dikatakan bahwa, orang dianggap memiliki daya tahan, kalau masih sanggup bekerjaterus menerus dalam periode waktu yang relatif lama.

Daya tahan aerobik menggambarkan kemampuan otot-otot besar dalam melakukan kegiatan dengan intensitas sedang, dalam waktu lama secara terus menerus. Penurunan daya tahan aerobik salah satunya diakibatkan oleh penurunan kadar hemoglobin, karena pengikatan oksigen yang berkurang. Kelelahan terjadi akibat penurunan daya tahan aerobik (Madina, 2007). Daya tahan aerobik merupakan salah satu dari komponen dari kondisi fisik. Daya tahan aerobik berhubungan dengan kemampuan jantung dan paru dalam memompa oksigen secara maksimal ke seluruh bagian tubuh(Sepriani \& Kurnia Rahman, 2019). Aktivitas fisik menyebabkan peningkatan tingkat metabolisme dan produksi panas yang mengakibatkan hilangnya air dan elektrolit dan deplesi glikogen di hati dan otot (Maughan \& Shirreffs, 2003). Hilangnya elemen-elemen ini dapat menyebabkan dehidrasi, yang mempengaruhi kinerja fisik dan merusak kesehatan.

Menurut Irawan (2007), semakin meningkatnya energi dan panas yang dihasilkan melalui proses metabolisme dan kontraksi otot saat tubuh sedang berolahraga, cairan yang berada didalam tubuh kemudian akan menjalankan fungsinya sebagai pengatur panas. Apabila proses berkurangnya cairan dalam tubuh pada saat berolahaga ini dibiarkan dalam jangka waktu yang lama dan tidak diimbangi dengan konsumsi cairan yang cukup, maka tubuh akan mengalami dehidrasi. Daya tahan aerobik seringdilihat dari VO2 maksimum yang didefinisikan sebagai laju konsumsi oksigen tertinggi yang dicapai selama ataulengkap latihanmaksimal.VO2 maksimummerupakan indikator terbaik untuk daya tahan aerob yang digunakan sebagai parameter pengukuran (Sepriani, 2017). 
JURNAL SPORTA SAINTIKA

P-ISSN 2502-5651

E-ISSN 2579-5910

Minum air putih pada saat olahraga dianggap bukan merupakan larutan yang ideal untuk mengoptimalisasi proses rehidrasi tubuh. Menurut penelitian Matsui (2002) konsentrasi kalium dan sodium (natrium) yang hilang melalui keringat adalah tinggi berbanding elektrolit lain. Penelitian Matsui merekomendasikan bahwa suplementasi penting bagi olahraga dengan intensitas ringan. Penambahan mineral tambahan seperti kalsium, magnesium, iron, fosforus, zink, dan kuprum pada diet tidak diperlukan.

Minuman isotonik adalah minuman yang dapat membantu menggantikan cairan dan elektrolit yang hilang melalui keluarnya keringat. Minuman isotonik dengan cepat meresap ke dalam tubuh karena osmolaritas yang baik dan terdiri dari elektrolit-elektrolit untuk membantu menggantikan cairan tubuh. Minuman isotonik memiliki komposisi elektrolit (ion positif dan ion negatif) yang mirip dengan cairan tubuh. Minuman isotonik mengandung air dan elektrolit dengan komposisi: gula, asam sitrat, natrium sitrat, natrium klorida, kalium klorida, kalium laktat, magnesium, karbonat dan perasa sitrus. Disebut isotonik karena keseimbangan kepekatan larutan yang sesuai dengan kepekatan cairan darah (Susanto, 2008).

Dengan klaim lebih baik daripada air biasa, kini berbagai jenis minuman isotonik menyerbu pasaran. Oleh karena itu, penelitian tentang minuman isotonik yang beredar menjadi kebutuhan untuk membuktikan kebenaran manfaat yang dijanjikan oleh produsennya. Hal ini menjadi penting, mengingat masyarakat sangat mudah terpengaruh dengan iklan-iklan yang sedikit persuasif meskipun belum jelas kebenaran dari produk yang diiklankan tersebut. Tidak hanya masyarakat, mahasiswa olahragapun sering mengkonsumsi minuman berfortifikasi khsusnya munuman isotonik.

\section{METODELOGI PENELITIAN}

Penelitian ini tergolong penelitian eksperimental semu. Penelitian ini bertujuan untuk menentukan sejumlah perubahan yang dihasilkan oleh perlakuan.Populasi dalam penelitian ini adalah mahasiswa FIK UNP.Sampel dalam penelitian ini diambil dengan menggunakan teknik purposive sampling yaitu pengambilan sampel yang dilakukan dengan tujuan tertentu yang memenuhi kriteria inklusi yaitu mahasiswa laki-laki, bersedia menjadi responden, berbadan sehat dan memiliki indeks masa tubuh normal sebanyak 20 orang. 
JURNAL SPORTA SAINTIKA

P-ISSN 2502-5651

E-ISSN 2579-5910

Bahan-bahan yang digunakan dalam penelitian ini adalah minuman isotonik. Alat-alat yang digunakan dalam penelitian ini adalah lintasan datar dan tidak licin (20 meter); meteran; kaset; tape recorder/radio tape player; format test, patok untuk menentukan jarak antara garis start dan finish. Data hasil penelitian dianalisis dengan menggunakan uji t.

\section{HASIL DAN PEMBAHASAN}

\section{A. HASIL}

Berdasarkan data penelitian awal (pre-test), diperoleh volume oksigen terendah 27,2 dan tertinggi 47,1. Dari analisis data didapatkan nilai volume oksigen maksimal $\left(\mathrm{VO}_{2}\right.$ maks) rata-rata sebesar 34,62, standar deviasi 5,86, Median 34. Distribusi frekuensi tampak pada tabel berikut ini:

Tabel 1. Distribusi Frekuensi Volume Oksigen Mkasimal (VO2 maks) Minuman Isotonik Pretest

\begin{tabular}{|c|c|c|c|}
\hline Kelas Interval & Frekuensi Absolut & Frekuensi Relatif (\%) & Klasifikasi \\
\hline$<33,0$ & 10 & 50 & Sangat Kurang \\
\hline $33,0-36,4$ & 3 & 15 & Kurang \\
\hline $36,5-42,4$ & 4 & 20 & Cukup \\
\hline $42,5-46,4$ & 2 & 10 & Baik \\
\hline $46,5-52,4$ & 1 & 5 & Sangat Baik Sekali \\
\hline$>52,4$ & 0 & 0 & \\
\hline Jumlah & 20 & 100 & \\
\hline
\end{tabular}

Dari tabel diatas dapat dilihat dari 20 orang sampel penelitian nilai volume oksigen maksimal (VO2 maks) yang paling banyak terdapat pada kelas interval $<33,0$ sebanyak 10 orang $(50 \%)$ yang berada pada klasifikasi sangat kurang, kelas interval $36,5-42,4$ sebanyak 4 orang (20\%) pada klasifikasi cukup, kelas interval 33,0-36,4 sebanyak 3 orang (15\%) pada klasifikasi kurang, kelas interval 42,5-46,4 sebanyak 2 orang (10\%) pada klasifikasi baik dan pada kelas interval 46,5-52,4 sebanyak 1 orang (5\%) pada klasifikasi baik sekali dan tidak ada satu orangpun yang berada pada kelas interval $>52,4$ pada klasifikasi sangat baik sekali.

Setelah diberikan minuman isotonik didapatkan nilai volume oksigen maksimal (VO2 maks) terendah 30,6 dan tertinggi 48,4. Dari analisis data didapatkan nilai volume oksigen maksimal ( $\mathrm{VO}_{2}$ maks) rata-rata sebesar 38,19, standar deviasi 5,19, Median 38. Distribusi frekuensi tampak pada tabel berikut ini: 
JURNAL SPORTA SAINTIKA

P-ISSN 2502-5651

E-ISSN 2579-5910

Tabel 2. Distribusi Frekuensi Volume Oksigen Mkasimal (VO2 maks) Minuman Isotonik Postest

\begin{tabular}{|c|c|c|c|}
\hline Kelas Interval & Frekuensi Absolut & Frekuensi Relatif (\%) & Klasifikasi \\
\hline$<33,0$ & 4 & 20 & Sangat Kurang \\
\hline $33,0-36,4$ & 4 & 20 & Kurang \\
\hline $36,5-42,4$ & 7 & 35 & Cukup \\
\hline $42,5-46,4$ & 4 & 20 & Baik \\
\hline $46,5-52,4$ & 1 & 5 & Saik Sekali \\
\hline$>52,4$ & 0 & 0 & \\
\hline Jumlah & 20 & 100 & \\
\hline
\end{tabular}

Dari tabel diatas dapat dilihat dari 20 orang sampel penelitian nilai volume oksigen maksimal (VO2 maks) yang paling banyak terdapat pada kelas interval < 36,5-42,4 sebanyak 7 orang (35\%) yang berada pada klasifikasi cukup, kelas interval $<33,0$ sebanyak 4 orang (20\%) pada klasifikasi sangat kurang, kelas interval 33,0-36,4 sebanyak 4 orang (20\%) pada klasifikasi kurang, kelas interval 42,5-46,4 sebanyak 4 orang (20\%) pada klasifikasi baik dan pada kelas interval 46,5-52,4 sebanyak 1 orang (5\%) pada klasifikasi baik sekali dan tidak ada satu orangpun yang berada pada kelas interval $>52,4$ pada klasifikasi sangat baik sekali.

\section{Nilai Rata-Rata Volume Oksigen maksimum Pretest dan Posttest}

Pada penelitian ini pengukuran VO2 maksimum pada subjek penelitian dilakukan sebelum dan sesudah diberikan minuman isotonik dengan menggunakan tes multi tahap atau bleep test. Hasil pengukuran VO2 maksimum sebelum diberikan minuman isotonik memiliki nilai rata-rata VO2 maksimum34,62. Tiga puluh menit setelah pemberian minuman isotonik dilakukan bleep test pada subjek dan diukur VO2 maksimum. Hasil pengukurannya menunjukkan terjadi peningkatan VO2 maksimum dimana nilai rata-rata VO2 maksimum 38,19. Untuk lebih jelasnya dapat dilihat pada tabel dibawah ini: 
JURNAL SPORTA SAINTIKA

P-ISSN 2502-5651

E-ISSN 2579-5910

Tabel 3. Nilai rata-rata VO2 maksimum

\begin{tabular}{|l|l|l|}
\hline \multirow{2}{*}{ No. } & \multicolumn{2}{|l|}{ Nilai rata-rata VO2 maksimum } \\
\cline { 2 - 3 } & Pretest & Posttest \\
\hline 1. & 34,62 & 38,19 \\
\hline
\end{tabular}

Untuk lebih jelasnya nilai rata-rata volume oksigen maksimum (VO2 maks) sebelum dan sesudah perlakuan dapat dilihat pada histogram dibawah ini:

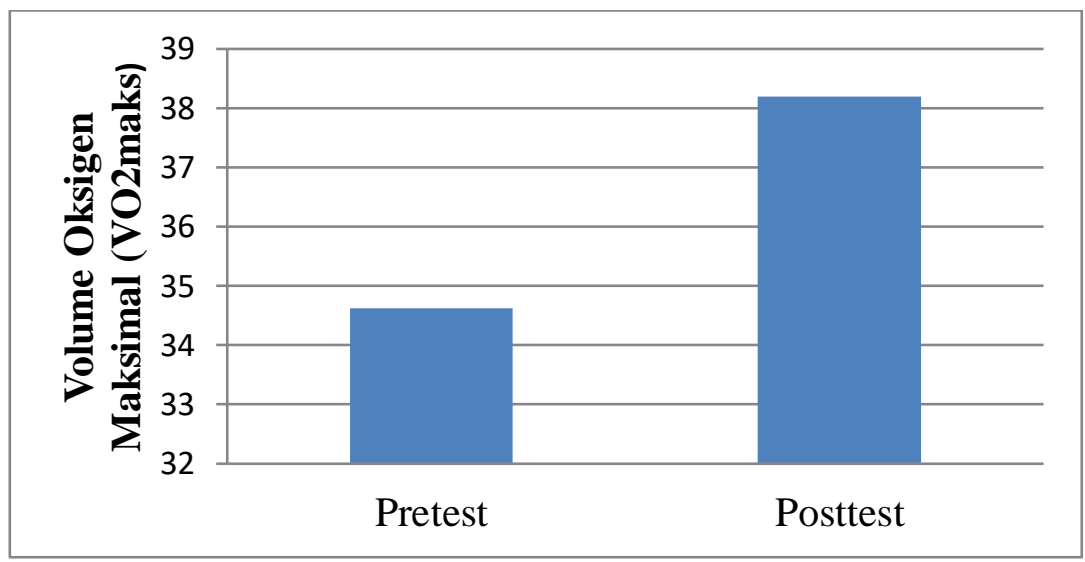

Histogram Nilai rata-rata VO2 maks

\section{PEMBAHASAN}

Daya tahan kardiorespirasi atau kapasitas aerobik merupakan komponen terpenting dari kebugaran jasmani. Seseorang dengan kapasitas aerobik yang baik memiliki jantung yang efisien, paru-paru yang efektif, peredaran darah yang baik pula, yang dapat menyuplai otot-otot sehingga yang bersangkutan mampu bekerja terus menerus tanpa mengalami kelelahan yang berlebihan. Daya tahan jantung paru dapat diukur melalui kadar VO2 maks yang dicapai, sehingga jika kadar VO2 maks yang dicapai sesuai target maka dapat memenuhi salah satu syarat kebugaran jasmani (Guyton, 2006).

Pada aktifitas fisik terjadi peningkatan konsumsi oksigen, peningkatan ini akan mencapai maksimal saat beban kerja. Hal ini berkaitan dengan VO2 maks (Guyton, 2006). VO2 maks menunjukkan kemampuan sistem kardiorespirasi untuk mengambil, membawa dan menggunakan oksigen untuk performa kerja selama latihan. 
JURNAL SPORTA SAINTIKA

P-ISSN 2502-5651

E-ISSN 2579-5910

Pengukuran ini biasanya sebagai salah satu indikator terbaik kebugaran fungsi kardiovaskuler dan daya tahan tubuh seseorang. Orang yang kebugarannya baik mempunyai nilai VO2 maks yang lebih tinggi dan dapat melakukan aktifitas fisik lebih kuat daripada mereka yang dalam kondisi tidak baik dimana VO2 maks dipengaruhi oleh faktor genetik dan lingkungan seperti gaya hidup, diet, dan latihan (Cengiz A, 2008 \& Patton, 2001).

Minuman isotonik yang diberikan memiliki komposisi elektrolit yang mirip dengan cairan tubuh. Minuman isotonik dalam kemasan yang berukuran $350 \mathrm{cc}$ dikonsumsi 30 menit sebelum melakukan tes. Minuman isotonik memiliki konsentrasi elektrolit $21 \mathrm{mEq} / \mathrm{L}$ natrium, $5 \mathrm{mEq} / \mathrm{L}$ kalium, $1 \mathrm{mEq} / \mathrm{L}$ calcium, $0.5 \mathrm{mEq} / \mathrm{L}$ magnesium, $16 \mathrm{mEq} / \mathrm{L}$ clorida, $10 \mathrm{mEq}$ sitrat dan $1 \mathrm{mEq}$ laktat.

Pengukuran VO2 maksimum sebagai salah satu parameter daya tahan aerobik dilakukan pada subjek penelitian sebelum dan sesudah diberikan minuman isotonik dengan menggunakan tes multi tahap atau bleep test. Hasil pengukuran VO2 maksimal sebelum diberikan minuman isotonik menunjukkan nilai rata-rata VO2 maks 34,62. Kemudian subjek diistirahatkan selama 10 hari dan diukur kembali nilai VO2 maks dimana diberikan minuman isotonik tiga puluh menit sebelum pengukuran dan didapatkan nilai VO2 maks 38,19.

Dari hasil analisis data didapatkan terdapat perbedaan yang signifikan VO2 maks sebelum diberikan minuman isotonik dengan setelah diberikan minuman isotonik dengan nilai thitung $(5,398604)>t_{\text {tabel }}(1,729)$ pada taraf signifikansi $\alpha=0,05$. Penelitian ini sejalan dengan yang dilakukan Azizah (2015) dimana dinyatakan bahwa tardapat perbedaan yang bermakna VO2 maks sebelum dan sesudah pemberian minuman isotonik. Hasil penelitian ini menunjukkan bahwa minuman isotonik berpengaruh terhadap peningkatan VO2 maks. Hal ini terjadi karena minuman isotonik merupakan minuman yang komposisinya mirip dengan cairan tubuh sehingga mudah diserap oleh tubuh. Dari kandungannya pun dapat dilihat bahwa minuman isotonik mengandung mineral yang sangat dibutuhkan oleh tubuh untuk melakukan aktivitas.

Ketika aktivitas fisik dilakukan seperti bekerja dan berolahraga, maka pada saat itu pula terjadi konsumsi energi, air dan mineral. Air hilang bersama air seni dan keringat. Sementara itu beberapa mineral hilang bersama keringat yang dikeluarkan. Secara normal (asupan makanan cukup), kebutuhan energi saat beraktivitas disuplai dari oksidasi lemak, karbohidrat dan sedikit kontribusi dari pemecahan protein, kira-kira $5 \%$. Semakin berat intensitas aktivitas fisik dilakukan maka akan semakin besar energi 
JURNAL SPORTA SAINTIKA

P-ISSN 2502-5651

E-ISSN 2579-5910

yang dibutuhkan dan akan semakin besar karbohidrat yang digunakan sebagai sumber energy (Koswara, 2006).

Keluarnya cairan tubuh melaui keringat berimbas pada keluarnya mineralmineral tubuh yang yang larut dalam air. Hal ini berbanding lurus dengan pendapat Wiarto (2013) yang menyatakan bahwa keringat ketika keluar juga akan membawa sejumlah elektrolit makro yaitu natrium, kalium dan klorida. Pendapat lain menurut Darmawan (2013) mengemukakan bahwa makin besar intensitas latihan, suhu dan kelembapan, akan semakin besar kehilangan air. Keluarnya air serta mineral seperti natrium, klor, kalium, kalsium, dan magnesium yang bertugas menjaga keseimbangan cairan didalam tubuh, menjaga irama jantung, serta relaksasi otot akan berimbas pada timbulnya rasa lelah. Kekurangan mineral-mineral yang terjadi karena proses ini dapat digantikan oleh minuman isotonik yang mengandung mineral-mineral yang dibutuhkan tubuh untuk mencegah terjadinya kekelahan dan mempercepat pemulihan.

\section{KESIMPULAN}

Berdasarkan hasil pembahasan diatas penelitian ini dapat di simpulkan :

1. Nilai rata-rata volume oksigen maksimum (VO2 maks) awal yaitu 34,62

2. Nilai rata-rata volume oksigen maksimum (VO2 maks) setelah diberikan minuman isotonik yaitu 38,19

3. Terdapat perbedaan yang bermakna secara statistik sebelum (pretest) dan sesudah (posttest) pemberian minuman isotonik terhadap daya tahan aerobik.

\section{SARAN}

Berdasarkan kesimpulan yang telah dikemukakan diatas, maka disarankan :

1. Penulis menyarankan apabila masyarakat membutuhkan asupan nutrisi untuk dehidrasi pada olahraga yang membutuhkan daya tahan aerobik dapat menggunakan minuman istonik.

2. Perlu dilakukan penyetaraan kemampuan fisik tiap subjek pada awal penelitian dengan lebih merincidurasi olahraga tiap minggunya.

3. Serta perlu dilakukan penelitian lebih lanjut mengenai pengaruh minuman isotonic terhadap daya tahan aerobic dengan metode pengukuran yang berbeda.

\section{DAFTAR PUSTAKA}

Anwari, Irawan M. 2007. Metabolisme Energi Tubuh dan Olah Raga. I Jurnal, Vol. 1 No.7 Bafirman. 2008. Buku Ajar Kondisi Fisik. Padang: FIK UNP. 
JURNAL SPORTA SAINTIKA

P-ISSN 2502-5651

E-ISSN 2579-5910

Cengiz A, Robert AR, lan K. 2008. Prediction of VO2 max from an Individualized

Submaximal Cycle Ergometer Protocol. JEP online 11: 3.

Darmawan, Aji Budi. 2013. Diet Sehat AirKelapa. Yogyakarta: Media Pressindo.

Guyton, A.C., Hall J.E. 2006. BukuAjar Fisiologi Kedokteran, Edisi ke-11. Jakarta: EGC.

Inoue, Y., T. Osawa, A. Matsui, Y. Asoi, Y, Murokami T. Matsui, and H. Yano. 2002.

Changes of Serum Mineral Concentration in horsis during exercise. Asian aust.J. Anim.Sci. 5 (4): 531-536.

Madina, D, 2007, Nilai Kapasitas Paru dan Hubungannya dengan Karakteristik Fisik pada Atlet Berbagai Cabang Olah Raga.

Patton H. 2001. Textbook of Physiology. Philadelpia: WB Saunders Company.

Sepriani, R. (2017). Pengaruh Pemberian Minuman Beroksigen Terhadap Kemampuan Volume Oksigen Maksimal (Vo2 Maks). Jurnal Menssana Vol.2. Retrieved from http://menssana.ppj.unp.ac.id/index.php/jm/article/view/27/20

Sepriani, R., \& Asnaldi, A. (2016). Efektivitas Minuman Energi Terhadap Daya Tahan Aerobik. Jurnal Mensana, Vol.3. Retrieved from http://sportasaintika.ppj.unp.ac.id/index.php/sporta/article/view/40/13

Sepriani, R., \& Kurnia Rahman, R. (2019). Daya Tahan Aerobik Pada Atlet Sekolah Sepakbola Usia 14-16 Tahun. Jurnal Menssana, 4(1). Retrieved from http://menssana.ppj.unp.ac.id/index.php/jm/article/view/34/27 